\title{
PENGARUH PEMAKANAN SECARA NORMAL DENGAN BERULANG TERHADAP KEKASARAN PERMUKAAN ALUMUNIUM ALLOY MENGGUNAKAN CAD-CAM-CNC 3A
}

\author{
Iskandar $^{1}$, Almadora Anwar Sani ${ }^{2}$, Dicky Seprianto ${ }^{3}$, Didi Suryana ${ }^{4}$ \\ 1,2,3,4 Jurusan Teknik Mesin, Politeknik Negeri Sriwijaya, \\ Jl. Sriwijaya Negara Bukit Besar Palembang 30139,Telp: 0711-352414, Fax: 0711-453211 \\ e-mail:'iiskandarr@yahoo.com, ${ }^{2}$ almadora@polsri.ac.id
}

\begin{abstract}
Technology of manufacturing expanded rapidly with the advent of software supporting machining. CAD software to help make engineering drawings. CAD integrated CAM and CNC in order to process the application. While the use of application software with a real application, there was a slight deviation on work piece surface roughness results. Research methods used by experiments. Material Test used Aluminum Alloy. Test roughness by using surface roughness. Work piece is drawn using $C A D$, then in the analysis of the program code using a CAM and then applied on the machine CNC 3A. A program made by comparing the influence of the consumption to normal with repeated consumption program in the same area. The consumption of normally returning by using CAD-CAMCNC $3 A$ can affect the work piece surface roughness. The highest level of roughness N5.
\end{abstract}

Key words : Surface Roughness, CAD, CAM, CNC $3 A$.

\begin{abstract}
ABSTRAK
Perkembangan teknologi manufaktur berkembang pesat dengan munculnya software pendukung pemesinan. Seperti software CAD yang banyak digunakan untuk membantu membuat gambar teknik. Pada pemesinan manufaktur CAD terintegrasi dengan CAM dan CNC guna proses aplikasi. Saat penggunaan aplikasi software dengan aplikasi nyata, ada sedikit penyimpangan pada hasil kekasaran permukaan benda kerja. Metode penelitian yang digunakan dengan eksperimen. Material Uji menggunakan Alumunium Alloy. Untuk mengetahui penyimpangan yang terjadi material di uji kekasaran dengan menggunakan surface roughness. Sebelum dilakukan pengujian benda kerjadi gambar menggunakan CAD, kemudian dianalisis kode program menggunakan CAM, lalu di aplikasikan pada mesin CNC 3A. Program yang dibuat dengan membandingkan pengaruh pemakanan normal dengan program pemakanan berulang di area yang sama. Pemakanan secara normal dengan berulang dengan menggunakan CAD-CAM-CNC 3A dapat mempengaruhi kekasaran permukaan benda kerja. Dengan nilai tingkat kekasaran N5.
\end{abstract}

Kata kunci : Kekasaran Permukaan, CAD, CAM , CNC 3A

\section{PENDAHULUAN}

$\begin{array}{llr}\text { Computer Aided Manufacturing (CAM) } \\ \text { merupakan } & \text { software r untuk } \\ \text { mengendalikan cutting tools dan } \\ \text { membuat kode pemrograman yang }\end{array}$ terdapat pada mesin CNC. Tujuan CAM untuk membuat proses produksi menjadi lebih cepat, ukuran yang presisi, dan konsistensi material pada komponen tools. Dimana dalam beberapa kasus, dapat mengurangi kebutuhan material dan juga konsumsi energi. CAM merupakan proses setelah pemodelan menggunakan Computer Aided Design (CAD) atau Computer Aided Engineering (CAE). Gambar yang telah dibuat menggunakan software CAD/CAE kemudian diolah oleh software CAM untuk akhirnya menjadi perintah berupa kode program untuk mengontrol cutting tools di mesin CNC

CAD/CAM digunakan bila model dikerjakan secara manual mengalami tingkat kesulitan pada proses simetris geometris dan membutuhkan waktu penyelesaian yang begitu lama. Serta 
ingin memproduksi bahan material manufaktur secara masal ${ }^{[3]}$.

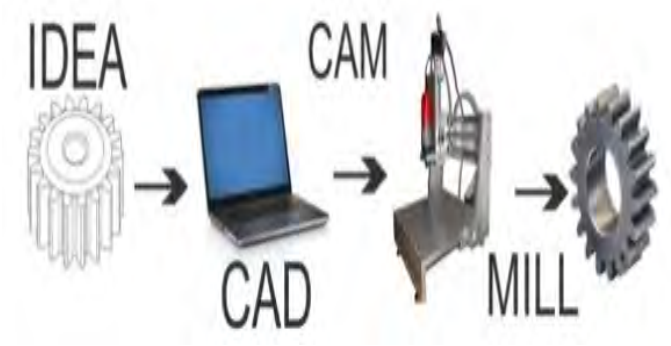

Gambar 1. Proses menuangkan ide menjadi bentuk aplikasi ${ }^{[10]}$

Permasalahan yang sering terjadi adalah hasil kekasaran permukaan benda hasil pengerjaan menggunakan CAM dengan CNC tidak sesuai. Oleh karena itu penelitian ini menguji kekasaran

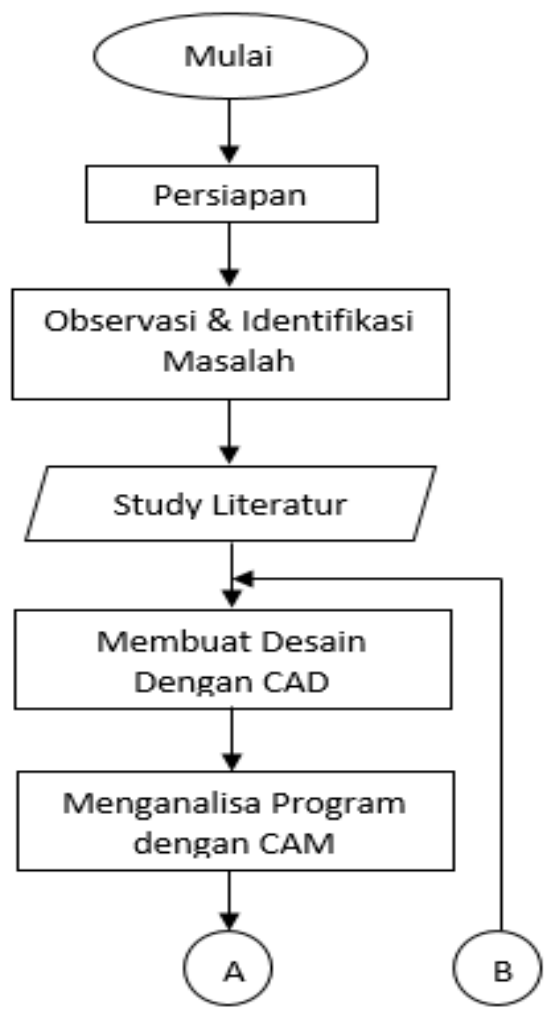

permukaan dengan mengetahui hasilnya menggunakan surface roughness tester.

\section{METODE PENELITIAN}

Penelitan ini menggunakan metoda Eksperimen. Penelitian dimulai dengan membuat desain menggunakan $\mathrm{CAD}$, kemudian diolah dengan CAM. Hasil disain kemudian disimulasikan dan diterapkan pada benda kerja dengan menggunakan mesin CNC 3A lalu di analisis kekasaran permukaannya. Material pengujian menggunakan Aluminium Alloy.

Urutan penelitian dapat dapat dijelaskan pada flowchart pada gambar 2 .



Gambar 2. Flowchart

Penelitian ini dimulai dengan mempersiapkan Material, Alat-alat pendukung, CAD, CAM dan Mesin CNC 3A (Milling/Frais). Parameter penelitian dilakukan dengan membandingkan proses pemakanan benda kerja. Yaitu : pemakanan normal 1 kali, pemakanan berulang 2, 3, dan 4 kali pada area yang sama. Dept of cut 1 $\mathrm{mm}$, federate $100 \mathrm{~mm} / \mathrm{menit}$, Cutter Speed 2000 rpm. Tanpa menggunakan coolant. 
Hipotesis :

H0 : Tidak ada pengaruh pemakanan berulang terhadap kekasaran permukaan benda kerja.

H1 : Ada pengaruh pemakanan berulang terhadap kekasaran permukaan benda kerja.

Analisis pengujian menggunakan ANOVA dengan taraf signifikasi 0,05.

\section{HASIL DAN PEMBAHASAN}

Bentuk benda kerja yang akan dilakukan pengujian digambar dengan CAD, dilanjutkan dengan CAM untuk menganalisa kode progam yang akan dieksekusi. Setelah selesai kode program kemudian diinput pada Mesin CNC 3A, dan siap untuk eksekusi pada benda kerja.

Hasil pengerjaan pada Mesin CNC 3A diuji kekasaran permukaan dengan alat Surface Roughness. Sehingga didapat hasil seperti tabel 1.

Tabel 1. Hasil pengujian kekasaran permukaan

\begin{tabular}{|c|c|c|c|c|}
\hline TitikUji & $\begin{array}{c}\text { Perlakuan 1 } \\
\text { Ra }(\mu \mathrm{m})\end{array}$ & $\begin{array}{c}\text { Perlakuan 2 } \\
\text { Ra }(\mu \mathrm{m})\end{array}$ & $\begin{array}{c}\text { Perlakuan 3 } \\
\text { Ra }(\mu \mathrm{m})\end{array}$ & $\begin{array}{c}\text { Perlakuan 4 } \\
\text { Ra }(\mu \mathrm{m})\end{array}$ \\
\hline 1 & 0,603 & 0,549 & 0,379 & 0,355 \\
\hline 2 & 0,553 & 0,561 & 0,323 & 0,47 \\
\hline 3 & 0,559 & 0,572 & 0,418 & 0,375 \\
\hline Rata-rata & $\mathbf{0 , 5 8 5}$ & $\mathbf{0 , 5 7 2}$ & $\mathbf{0 , 3 7 3}$ & $\mathbf{0 , 4}$ \\
\hline
\end{tabular}

Hasil pengujian kekasaran permukaan H0 ditolak. Jika F Hitung< F tabel maka dianalisis dengan ANOVA. Dengan H0 diterima.

ketentuan, Jika F Hitung> F tabel maka

Tabel 2. SUMMARY

\begin{tabular}{lrrrr}
\hline \multicolumn{1}{c}{ Groups } & \multicolumn{1}{c}{ Count } & \multicolumn{1}{c}{ Sum } & Average & \multicolumn{1}{c}{ Variance } \\
\hline Perlakuan 1 & 3 & 1.755 & 0.585 & 0.000772 \\
Perlakuan 2 & 3 & 1.682 & 0.561 & 0.000132 \\
Perlakuan 3 & 3 & 1.12 & 0.373 & 0.00228 \\
Perlakuan 4 & 3 & 1.2 & 0.4 & 0.003775 \\
\hline
\end{tabular}

Tabel 3. ANOVA

\begin{tabular}{lcrcccc}
\hline $\begin{array}{l}\text { Source of } \\
\text { Variation }\end{array}$ & SS & $d f$ & MS & $F$ & P-value & F crit \\
\hline $\begin{array}{l}\text { Between } \\
\text { Groups } \\
\text { Within }\end{array}$ & 0.105928917 & 3 & 0.035309639 & 20.29387 & 0.000426 & 4.066181 \\
Groups & 0.013919333 & 8 & 0.001739917 & & & \\
Total & 0.11984825 & 11 & & & & \\
\hline
\end{tabular}


Dari data di atas diperoleh Fhitung sebesar 20,29387 karena 20,29387 > 4,07 maka H0 ditolak, sehingga dengan menggunakan taraf signifikansi 0,05.
Maka dapat disimpulkan bahwa ada perbedaan rata-rata pemakanan berulang dengan hasil kekasaran permukaan benda kerja.

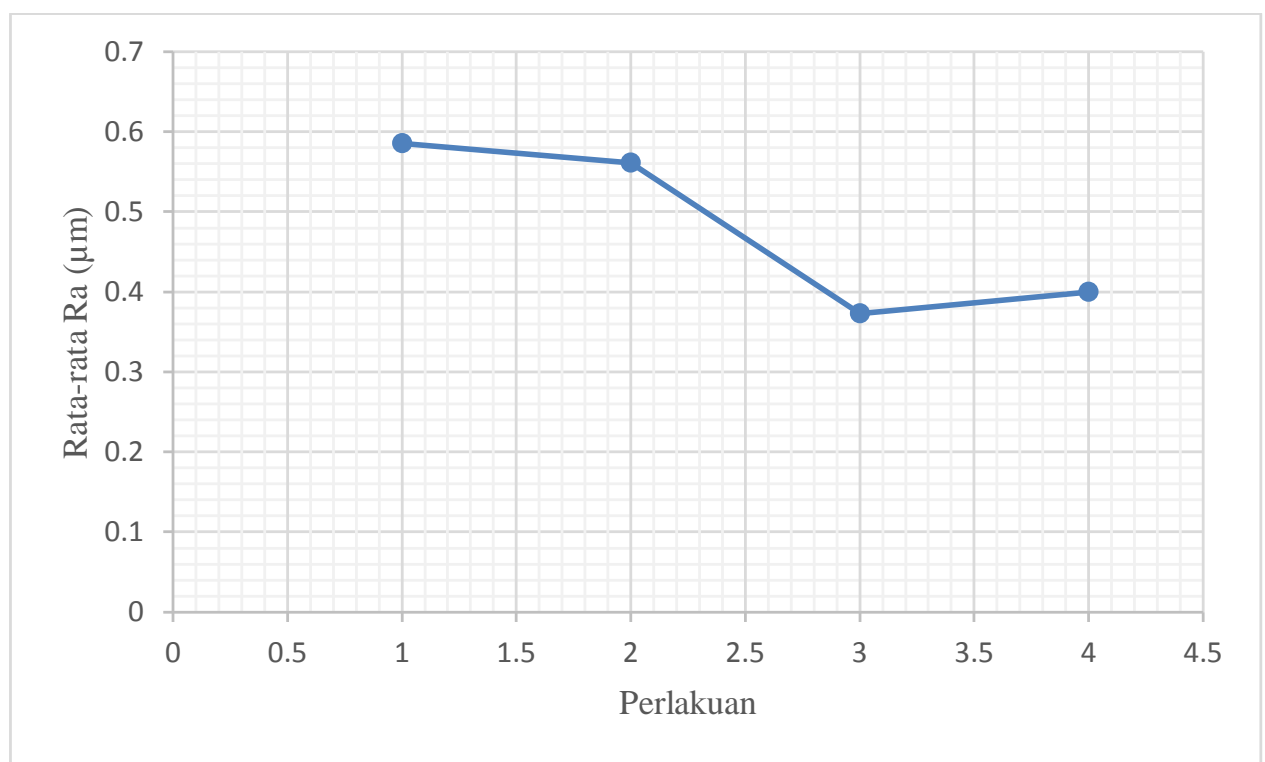

Gambar 3. Grafik uji kekasaran permukaan

Pemakanan berulang dapat membuat nilai kekasaran menjadi lebih halus. Perlakuan 1 nilai rata-rata kekasaran $0,585 \mu \mathrm{m}$. Perlakuan 2 nilai rata-rata kekasaran 0,572 $\mu \mathrm{m}$. Perlakuan 3 nilai rata-rata $0,373 \mu \mathrm{m}$. Perlakuan 4 nilai rata-rata $0,4 \mu \mathrm{m}$.

Perlakuan 1 merupakan pemakanan normal, perlakuan 2 merupakan pemakanan berulang sebanyak 2 kali, perlakuan 3 pemakanan berulang sebanyak 3 kali, dan perlakuan 4 pemakanan berulang sebanyak 4 kali. Pemakanan berulang sebanyak 3 kali memiliki nilai rata-rata kekasaran 0,373 $\mu \mathrm{m}$ dengan tingkat kekasaran N5.

\section{KESIMPULAN}

Hasil perlakuan pemakanan berulang diperoleh data rata-rata kekasaran permukaan yaitu Pemakanan normal atau 1 kali diperoleh $\mathrm{Ra}$ 3,585 $\mu \mathrm{m}$, pemakanan berulang 2 kali diperoleh $\mathrm{Ra}$ $0,561 \mu \mathrm{m}$, pemakanan berulang $3 \mathrm{kali}$ diperoleh $\mathrm{Ra}$ 0,373 $\mu \mathrm{m}$, pemakanan berulang 4 kali diperoleh $\mathrm{Ra} 0,4 \mu \mathrm{m}$, Hasil analisis menggunakan ANOVA. Hipotesis : Jika F Hitung $>\mathrm{F}$ tabel maka H0 ditolak, Jika F Hitung < F tabel maka H0 diterima. Hasil data tersebut diperoleh $\mathrm{F}$ hitung sebesar 20,29387 karena 20,29387 > 4,07 maka H0 ditolak, sehingga dengan menggunakan taraf signifikansi 0,05. Pemakanan berulang mempengaruhi kekasaran permukaan benda kerja alumunium alloy. Perbedaan rata-rata pemakanan berulang dengan hasil kekasaran permukaan benda kerja memilki nilai tingkat kekasaran N5.

\section{UCAPAN TERIMAKASIH}

Ucapan Terima Kasih kepada PNBP Politeknik Negeri Sriwijaya yang telah membiayai kegiatan penelitian ini, hingga selesai penelitian. 


\section{DAFTAR PUSTAKA}

[1] Sationo A., \& Sisminto, 2010, Autodesk Inventor Professional 2009. Andi Yogyakarta, ISBN 978979-29-1312-5

[2] Tuakia F., 2008, Pemodelan CAD 3D Menggunakan Inventor. Informatika Bandung, ISBN 978979-1153-61-4.

[3] Ningsih D.H.U., Computer Aided Design / Computer Aided Manufacture (CAD/CAM), Jurnal Teknologi Informasi DINAMIK Volume X, No. 3, September 2005 :143-149, ISSN : 0854-9524.

[4] Hidayat T., dkk, 2016, Analisis Kekasaran Permukaan Terhadap Spindle Speed Dan Feeding Pada Proses Surface Milling Menggunakan Mesin Cnc Dengan Teknologi Cam. Jurnal Austenit Volume 8, No. 1, April 2016, ISSN : 2085-1286.

[5] Seprianto D., 2013, Pengaruh Parameter Pemesinan Terhadap Kekasaran Permukaan Benda Kerja Pada Mesin Cnc Type Edu Vr1Mill. Jurnal Austenit Volume 5, No.1, April 2013, ISSN : 20851286.

[6] Suryana D., dkk, 2015, Pengaruh Dept Of Cut Dan Feedrate Dengan Cutter Diameter $60 \mathrm{Mm}$ Terhadap Kerataan Permukaan Material Astm A36 Pada Mesin Mitsubishi CncMill 3A. Jurnal Austenit Volume 7, No. 1, April 2015, ISSN : 20851286.

[7] Suryana D., dkk, 2014, Pengaruh Media Pendingin Dan Kondisi Pemotongan Baja Aisi 1045 Terhadap Kekasaran Permukaan Pada Proses Cnc Milling. Jurnal Austenit Volume 6, No.1, April 2014, ISSN : 2085-1286.

[8] Sovannara C., dkk, 2016, Analisa Pengaruh Proses Permesinan Mesin Cnc Milling Terhadap Kekasaran Permukaan Pada Material Baja 9smn36 1.0736. Jurnal Austenit Volume 8, No.2, April 2016, ISSN : 2085-1286.

[9] Yunus M., dkk, 2012, Analisa Parameter Kekasaran Permukaan Bahan Alumunium Jenis Al Mg Si 3.6082 Din 1725 Pada Proses Pemesinan Cnc Milling. Jurnal Austenit Volume 4, No. 1 April 2012, ISSN : 2085-1286.

[10] http://www.ekits.eu/PROCNCDra w/ 18 April 2018. 
Iskandar dkk, Pengaruh Pemakanan Secara... 